\title{
STUDY OF SEMEN CHARACTERISTICS AT SEXUAL MATURITY IN AWASSI LAMBS FED ON LOW DEGRADABLE SUNFLOWER MEAL AND SEEDS
}

\section{Safwan L. Shihab, Omar D. Mohammed, Falah H. Ahmed}

Anim. Prod. Dept. College of Agric. \& Forestry, University of Mosul, Iraq

\begin{tabular}{l} 
Article information \\
Article history: \\
Received 18/5/2021 \\
Accepted 1/6/2021 \\
Available 31/7/2021 \\
\hline
\end{tabular}

Keywords:

protein and fat degradability

semen traits

seminal plasma.

DOI:

$\underline{10.33899 / \text { magrj.2021.130161.1130 }}$

Correspondence

Email: Safwan.1.s@uomosul.edu.iq

\section{ABSTRACT}

This study was conducted using 18 Awassi male lambs with an average initial weight $33.57 \pm 0.69 \mathrm{~kg}$ for the period from 9-12 months of age. Lambs were distributed randomly into three treatments each, included 6 lambs. Lambs in the first treatment $\left(\mathrm{T}^{1}\right)$ were fed a diet that includes $11 \%$ of sunflower meal, the second treatment $\left(\mathrm{T}^{2}\right)$ fed diet includes $11 \%$ of low degradable sunflower meal, and the third treatment $\left(\mathrm{T}^{3}\right)$ were fed on a diet containing $11 \%$ low degradable sunflower seed. The results were indicated a significant increase $(\mathrm{P} \leq 0.05)$ in semen volume in $\left(\mathrm{T}^{2}\right) 2.77 \mathrm{ml}$ compared with the $\left(\mathrm{T}^{1}\right) 1.98 \mathrm{ml}$ and $\left(\mathrm{T}^{2}\right) 1.69 \mathrm{ml}$. Significant improve $(\mathrm{p} \leq 0.05)$ was noted in $\mathrm{T}^{2}$ and $\mathrm{T}^{3}$ in individual motility 87.33 and $87.70 \%$ and sperm concentration 2.45 and $2.62 \times 10^{9} / \mathrm{ml}$ compared to the $\mathrm{T} 1$ the individual motility was $84.95 \%$ and sperm concentration $2.10 \times 10^{9} / \mathrm{ml}$, respectively. Seminal plasma concentration of total protein, globulin, and urea were higher $(\mathrm{P} \leq 0.05)$ in $\mathrm{T}^{2}$ as compared other treatments. Whereas, feeding low degradable sunflower seed $\left(\mathrm{T}^{3}\right)$ resulted in a significant increase $(\mathrm{P} \leq 0.01)$ of cholesterol concentration $140.05 \mathrm{mg} / \mathrm{dl}$ in seminal plasma compared with the $\mathrm{T} 1122.78 \mathrm{mg} / \mathrm{dl}$ and $\mathrm{T}^{2} 125.81 \mathrm{mg} / \mathrm{dl}$, while triglycerides was decreased $(\mathrm{P} \leq 0.05)$ in $\mathrm{T} 137.49 \mathrm{mg} / \mathrm{dl}$ than $\mathrm{T}^{2}$ and $\mathrm{T}^{3} 52.72$ and $58.92 \mathrm{mg} / \mathrm{dl}$ respectivly.

College of Agriculture and Forestry, University of Mosul.

This is an open access article under the CC BY 4.0 license (https://magrj.mosuljournals.com/ ).

\section{INTRODUCTION}

Male fertility is considered very important to any successful breeding program, higher fertility is associated with obtaining better quality semen and this achieves higher pregnancy rates in females, good nutrition affects male reproductive, either by improving energy state in the body or by increasing some metabolic substances that affect physiologically in the secretion of hormones related to reproduction and that regulate the work of testis and sperm production, It has been observed that a diet high in protein above the rumen micro-organisms requirements for protein synthesis, leads to an increase in the concentration of urea in the blood plasma, which in turn is able to reach the seminal tubes in the testis and make an important role in the process of sperm formation and secretion of testosterone as a result of the mutual relationship between energy and protein intake from side and reproductive performance (Gonzalez et al., 2000, Yasothai 2014). On the other hand, feeding males on fats that differed in the degree of unsaturation may be associated with improved reproductive characteristics (Safurinejad et al., 2010) through by 
maintaining the vitality and integrity of the sperm membranes, this is because unsaturated fatty acids represent about $60 \%$ of the phospholipids that make up sperm. Studies have unanimously agreed that the effect of lipid on male reproductive efficiency is achieved in two ways, the first is short-term, acting on the hormonal nervous system that regulates the functioning of the testis (Martin et al., 1994A), The second is long-term, through influencing the condition of the body and the growth of the testicles (Oldham et al., 1978). this study carried out to investigate the effect of feeding low degradable sunflower meal or seeds on semen characteristics and seminal plasma measurements in Awassi male lambs.

\section{MATERIALS AND METHODS}

This study was conducted in an animal barn at the Animal Production Department / College of Agriculture and Forestry, University of Mosul. Eighteen Awassi male lamb was used with an average body weight of $(33.57 \pm 0.69) \mathrm{kg}$ for the period from 9-12 months of age. The lambs were divided into three groups (6 lambs per treatment), the first treatment was fed on a diet contained $11 \%$ sunflower meal, second and third treatments were fed a diet contained $11 \%$ of formaldehyde protected sunflower meal and formaldehyde protected sunflower seeds.

Table (1): Chemical components and composition of the experimental diets.

\begin{tabular}{|l|c|c|c|}
\hline \multirow{2}{*}{\multicolumn{1}{|c|}{ Ingredients }} & \multicolumn{3}{c|}{ Experimental diets } \\
\cline { 2 - 4 } & T1 & T2 & T3 \\
\hline Crushed barley & 65 & 65 & 64.8 \\
\hline Wheat bran & 17 & 17 & 18 \\
\hline Sunflower meal & 11 & --- & --- \\
\hline low degradable sunflower meal & --- & 11 & --- \\
\hline low degradable sunflower seeds & --- & --- & 11 \\
\hline Wheat straw & 5.35 & 5.35 & 4 \\
\hline Urea & 0.15 & 0.15 & 0.70 \\
\hline Limestone & 0.5 & 0.5 & 0.5 \\
\hline Sodium chloride & 0.5 & 0.5 & 0.5 \\
\hline Sodium bicarbonate & 0.5 & 0.5 & 0.5 \\
\hline \multicolumn{2}{|c|}{} & \\
\hline Dry matter & 91.62 & 91.62 & 92.43 \\
\hline Organic matter & 96.01 & 96.01 & 95.91 \\
\hline Crude protein & 13.62 & 13.62 & 13.47 \\
\hline Ether extract & 2.41 & 2.41 & 7.40 \\
\hline Crud fiber & 11.50 & 11.50 & \\
\hline Metabolism energy, MJ / kg & 10.15 & 10.15 & 11.32 \\
\hline
\end{tabular}

Chemical composition was laboratory determined according to AOAC (3), the energy was calculated from the tables of the chemical composition of Iraqi feed materials (Al-Khawaja et al., 1978).

Lambs were fed ad-libitum on experimental diets through the experimental period and the actual intake was recorded daily, all lambs have a free access to clean water. Semen was collected from the lambs monthly using the Ejaculator method, according to (Fourie et al., 2004, Al-Hassan 2018). After collection, the semen was placed in a water bath at a temperature of $\left(37 \mathrm{C}^{0}\right)$ and the measurements of semen 
were recorded immediately include volume, color according to Ajam et al., (1981), mass activity, individual motility, proportion of live, dead and abnormal spermatozoa were estimated using an optical microscope according to (Loskutoff and Crichton 2001, Al Hassan 2009). Sperm concentration was calculated using a hemocytometer method according to (Smith and Mayer 1955). Seminal plasma was separated using a centrifuge $\left(4000 \mathrm{rpm} /\right.$ minute) for 30 minutes and kept under $\left(-20^{\circ} \mathrm{C}\right)$ for further analysis. Also, a sample of blood was withdrawn from the jugular vein using a plastic syringe, and serum was separated by a centrifuge (3000 rpm/minute) for 20 minutes. Seminal and plasma concentrations of proteins, glucose, cholesterol, triglycerides, and urea were estimated using commercial agent kit (Biolabo, French) by spectrophotometer (Biotech Engineering Management CO.LTD.UK). The data were statistically analyzed using a complete random design (CRD) application (SAS 2005), and the significant differences between among means tested according to Duncan test (1955).

\section{RESULTS AND DISCUSSION}

Results in table (2) showed a significant increase $(\mathrm{P} \leq 0.05)$ in the second treatment in semen volume $2.77 \mathrm{ml}$ compared to the first $1.98 \mathrm{ml}$ and the third 1.69 $\mathrm{ml}$ treatments. Also, a significant $(\mathrm{p} \leq 0.05)$ improve were noted in semen color in the second and third treatments 3.35 and 3.56, individual motility 87.33 and $87.70 \%$, live sperm percentage 91.20 and $91.25 \%$ and semen concentration 2.45 and $2.62 \times$ $10^{9} / \mathrm{ml}$, respectively, compared with the first treatment the color was 2.92 , individual motility $84.95 \%$, live sperm percentage $89.93 \%$ and concentration $2.10 \times 10^{9} / \mathrm{ml}$, this finding is in agreement with studies (Zaghloul et al., 2015; El-Zelaky et al., 2011;Saleh, 2009 and Fernandez et al., 2004) who found that feeding at different levels of undegradable protein led to a significant increase in the ejaculated volume. Similarly (Ezazi et al., 2019, Radmanesh et al., 2015, Shimon et al., 2011) they explained that feeding lambs on diets treated with formaldehyde or feeding low degradable fats showed a significant $(\mathrm{p} \leq 0.05)$ improvement in sperm concentration, percent of live sperm and individual motility. In contrast (Ali et al., 2005, Fernandez et al., 2005) reported that feeding lambs on diets contain low degradable protein did not lead to significant differences in sperm concentration and live sperm percentage, also, El-Madawy et al, (2019) indicated that feeding lambs with different levels of fish oil achieved a significant increase in semen volume. in the present study feeding lambs on low degradable meal and seeds reduce the percentage of dead sperm 8.80 and $8.75 \%$ compared to the first treatment $(10.07 \%)$. Whereas, the differences were not significant between the treatments mass activity $4.23,4.44$ and 4.47 and abnormal sperm $2.49,2.10$ and $2.41 \%$, respectively. In general, the percentage of abnormal sperms in all treatments was within the normal range $10 \%$ as indicated by Gimenez and Rodning (2007).

It is noted from the results that the best sperm characteristics were recorded in $\mathrm{T} 2$, and this may be related to an increase in the ratio of undegradable protein to the energy, which may have a direct effect on the testis by stimulating anabolic hormones such as insulin and insulin-like growth factor, which play an important role in their effect on hormonal receptors ( FSH and L.H) at the testis level and Sertoli cell development (El-Zelaky et al., 2011, Pinilla et al., 2012), However, Hotzel et al., (1998) indicated that sperm formation is sensitive to an increase in protein intake due 
to its association with an increase in testicular size and the size and diameter of the spermatic tubes, the enhancement in most semen traits in ram lambs fed low degradable sunflower seed may be due to the high concentration of unsaturated fatty acids especially linoleic acid which can be combined with fat sperm, leading to changes in the fluidity and elasticity of the sperm membrane (Conquer et al., 2000). On the other hand, the size of the scrotum and the high concentration of testosterone, which provides a good environment for sperm in the testis (Kumar et al. 2017).

Table (2): Effect of low degradable sunflower meal and seed on semen characteristics.

\begin{tabular}{|c|c|c|c|c|c|}
\hline Treatments & $\begin{array}{c}\text { Volume } \\
/ \mathrm{ml}\end{array}$ & Color & $\begin{array}{c}\text { Individual } \\
\text { motility } \\
\%\end{array}$ & $\begin{array}{c}\text { Mass } \\
\text { motility }\end{array}$ & $\begin{array}{c}\text { Concertation } \\
\times 10^{9}\end{array}$ \\
\hline sunflower meal & $\begin{array}{c}1.98 \pm \\
0.07 \mathrm{~b}\end{array}$ & $\begin{array}{c}2.94 \pm \\
0.12 \mathrm{~b}\end{array}$ & $\begin{array}{c}84.95 \pm \\
2.50 \mathrm{~b}\end{array}$ & $\begin{array}{c}4.23 \pm \\
0.18 \mathrm{a}\end{array}$ & $\begin{array}{c}2.10 \pm 0.08 \\
\mathrm{~b}\end{array}$ \\
\hline low degradable & $2.77 \pm$ & $3.35 \pm$ & $87.33 \pm$ & $4.44 \pm$ & $2.45 \pm 0.19$ \\
sunflower meal & $0.18 \mathrm{a}$ & $0.17 \mathrm{a}$ & $1.70 \mathrm{a}$ & $0.11 \mathrm{a}$ & $\mathrm{a}$ \\
\hline low degradable & $1.69 \pm$ & $3.56 \pm$ & $87.70 \pm$ & $4.47 \pm$ & $2.62 \pm 0.16$ \\
sunflower seed & $0.09 \mathrm{~b}$ & $0.14 \mathrm{a}$ & $1.95 \mathrm{a}$ & $0.14 \mathrm{a}$ & $\mathrm{a}$ \\
\hline
\end{tabular}

a,b, Means values within a column with different superscripts differed $(\mathrm{P} \leq 0.05)$.

Table (3): Effect of low degradable sunflower meal and seed on live, dead abnormal semen.

\begin{tabular}{|c|c|c|c|}
\hline Traits & Live sperm \% & Dead sperm \% & abnormal sperm \% \\
\hline sreatments & $89.93 \pm 1.83 \mathrm{~b}$ & $10.07 \pm 0.93 \mathrm{a}$ & $2.49 \pm 0.27 \mathrm{a}$ \\
\hline $\begin{array}{c}\text { low degradable } \\
\text { sunflower meal }\end{array}$ & $91.20 \pm 1.24 \mathrm{a}$ & $8.80 \pm 0.96 \mathrm{~b}$ & $2.10 \pm 0.21 \mathrm{a}$ \\
\hline $\begin{array}{c}\text { low degradable } \\
\text { sunflower seeds }\end{array}$ & $91.25 \pm 1.40 \mathrm{a}$ & $8.75 \pm 1.15 \mathrm{~b}$ & $2.41 \pm 0.29 \mathrm{a}$ \\
\hline
\end{tabular}

a,b, Means values within a column with different superscripts differed $(\mathrm{P} \leq 0.05)$.

It appears from table (4) there were no significant differences in the total protein concentration of $6.74,6.84$ and $6.29 \mathrm{~g} / \mathrm{dl}$, albumin $3.59,3.67$ and $3.64 \mathrm{~g} / \mathrm{dl}$, and globulin 3.16, 3.16 and $2.65 \mathrm{~g} / \mathrm{dl}$, glucose 62.52, 67.79, and $66.61 \mathrm{mg} / \mathrm{dl}$, and triglycerides 44.27, 47.44, and $44.31 \mathrm{mg} / \mathrm{dl}$, respectively. Blood urea concentration was higher significantly $(\mathrm{p} \leq 0.05)$ in $\mathrm{T} 253.56 \mathrm{mg} / \mathrm{dl}$ as compared $\mathrm{T} 141.74 \mathrm{mg} / \mathrm{dl}$ and T3 $40.22 \mathrm{mg} / \mathrm{dl}$, this increase may be due to excess availability of amino acids over the metabolic requirement of animals, Haro et al., (2020) indicated a positive association of amino acid metabolism in the liver and urea in the blood. A significant increase $(\mathrm{p} \leq 0.01)$ were observed in serum cholesterol concentration in T3 (185.18 $\mathrm{mg} / \mathrm{dl}$ ) compared $\mathrm{T} 1$ and $\mathrm{T} 2$ which was (114.71 and 133.74) $\mathrm{mg} / \mathrm{dl}$ respectively. These results resemble those of Al-Mallah (2007) who found that feeding lambs on diets treated with formaldehyde led to an increase in the urea concentration compared to the non-treatment, other studies (Hussein et al., 2018, Abdel-Ghani et al., 2011) 
indicated that feeding lambs on a low degradable sunflower meal or feeding with different levels of undegradable protein showed a significant decrease in blood urea concentrations. Also, studies of (Majewska et al., 2016, Radmanesh et al., 2015, Hadipour et al., 2014), found that feeding lambs on undegradable fat led to an increase in the concentration of cholesterol in the blood plasma.

Table (4): The effect of low degradable sunflower meal and seed on some blood parameters.

\begin{tabular}{|c|c|c|c|c|c|c|}
\hline Parameters & $\begin{array}{c}\mathrm{TP} \\
\mathrm{gm} / \mathrm{dl}\end{array}$ & $\begin{array}{c}\text { Alb } \\
\underset{*}{\mathrm{gm} / \mathrm{dl}}\end{array}$ & $\begin{array}{c}\mathrm{G} \\
\mathrm{mg} / \mathrm{dl}\end{array}$ & $\begin{array}{l}\text { Cho } \\
\mathrm{mg} / \mathrm{dl} \\
* *\end{array}$ & $\begin{array}{c}\mathrm{TG} \\
\mathrm{mg} / \mathrm{dl}\end{array}$ & $\underset{*}{\mathrm{U}} \underset{*}{\mathrm{mg}}$ \\
\hline sunflower meal & $\begin{array}{r}6.74 \pm \\
0.14 \mathrm{a}\end{array}$ & $\begin{array}{l}3.59 \pm \\
0.17 \mathrm{a}\end{array}$ & $\begin{array}{c}62.52 \pm \\
2.49 \mathrm{a}\end{array}$ & $\begin{array}{c}114.71 \pm \\
7.85 \mathrm{~b}\end{array}$ & $\begin{array}{c}44.27 \pm \\
2.42 \mathrm{a}\end{array}$ & $\begin{array}{c}41.74 \pm \\
3.13 \mathrm{~b}\end{array}$ \\
\hline $\begin{array}{l}\text { low degradable } \\
\text { sunflower meal }\end{array}$ & $\begin{array}{r}6.84 \pm \\
0.24 \mathrm{a} \\
\end{array}$ & $\begin{array}{l}3.67 \pm \\
0.04 \mathrm{a}\end{array}$ & $\begin{array}{c}67.79 \pm \\
3.15 \mathrm{a} \\
\end{array}$ & $\begin{array}{c}133.74 \pm \\
6.11 \mathrm{~b} \\
\end{array}$ & $\begin{array}{c}47.44 \pm \\
2.96 \mathrm{a} \\
\end{array}$ & $\begin{array}{r}53.56 \pm \\
2.42 \mathrm{a} \\
\end{array}$ \\
\hline $\begin{array}{l}\text { low degradable } \\
\text { sunflower seeds }\end{array}$ & $\begin{array}{r}6.29 \pm \\
0.38 \mathrm{a}\end{array}$ & $\begin{array}{l}3.64 \pm \\
0.03 \mathrm{a}\end{array}$ & $\begin{array}{c}66.61 \pm \\
6.30 \mathrm{a}\end{array}$ & $\begin{array}{c}185.18 \pm \\
10.63 \mathrm{a}\end{array}$ & $\begin{array}{c}44.31 \pm \\
3.13 \mathrm{a}\end{array}$ & $\begin{array}{r}40.22 \pm \\
2.19 \mathrm{~b}\end{array}$ \\
\hline
\end{tabular}

TP: total protein, Alb: albumin, G: glucose, Cho: cholesterol, TG: triglycerides, U: urea.

* a,b, Means values within a column with different superscripts differed $(\mathrm{P} \leq 0.05)$.

** a,b, Means values within a column with different superscripts differed $(\mathrm{P} \leq 0.01)$.

Results of the table (5) indicate that feeding lambs on a low-degradable sunflower meal (T2) resulted in a significant increase $(\mathrm{p} \leq 0.05)$ in total protein concentration $6.73 \mathrm{~g} / \mathrm{dl}$, globulin $3.92 \mathrm{~g} / \mathrm{dl}$, and urea concentration $46.20 \mathrm{mg} / \mathrm{dl}$ compared with the (T3), total protein reached $5.58 \mathrm{~g} / \mathrm{dl}$, globulin $2.48 \mathrm{~g} / \mathrm{dl}$, and urea $38.63 \mathrm{mg} / \mathrm{dl}$. Urea concentration increased $(\mathrm{p} \leq 0.05)$ in $\mathrm{T} 2$ as compared with the T1 and T3 (40.79 and $38.63 \mathrm{mg} / \mathrm{dl})$ respectively, whereas Cholesterol increase $(\mathrm{p} \leq 0.05)$ in the (T3) $140.05 \mathrm{mg} / \mathrm{dl}$ compared with T1 and T2 $(122.78$ and $125.81 \mathrm{mg} / \mathrm{dl})$ respectively. Triglycerides increased significantly $(\mathrm{p} \leq 0.05)$ in the T2 and T3 (52.72 and $58.97 \mathrm{mg} / \mathrm{dl})$ compared with $\mathrm{T} 1(37.49 \mathrm{mg} / \mathrm{dl})$. The differences between treatments in the albumin concentrations 2.69, 2.81, and $3.10 \mathrm{~g} / \mathrm{dl}$, were not significant.

Table (5): Effect of low degradable sunflower meal and seed on seminal plasma traits.

\begin{tabular}{|c|c|c|c|c|c|c|}
\hline Treatments & $\begin{array}{c}\mathrm{TP} \\
\mathrm{gm} / \mathrm{dl}\end{array}$ & $\begin{array}{c}\mathrm{Alb} \\
\mathrm{gm} / \mathrm{dl}\end{array}$ & $\begin{array}{c}\mathrm{G} \\
\mathrm{mg} / \mathrm{dl}\end{array}$ & $\begin{array}{c}\text { Cho } \\
\mathrm{mg} / \mathrm{dl}\end{array}$ & $\begin{array}{c}\mathrm{TG} \\
\mathrm{mg} / \mathrm{dl}\end{array}$ & $\begin{array}{c}\mathrm{U} \\
\mathrm{mg} / \mathrm{dl}\end{array}$ \\
\hline sunflower meal & $6.09 \pm$ & $2.69 \pm$ & $3.39 \pm$ & $122.78 \pm$ & $37.49 \pm$ & $40.79 \pm$ \\
& $0.33 \mathrm{a} \mathrm{b}$ & $0.22 \mathrm{a}$ & $0.15 \mathrm{a}$ & $5.83 \mathrm{~b}$ & $3.43 \mathrm{~b}$ & $1.10 \mathrm{~b}$ \\
\hline low degradable & $6.73 \pm$ & $2.81 \pm$ & $3.92 \pm$ & $125.81 \pm$ & $52.72 \pm$ & $46.20 \pm$ \\
sunflower meal & $0.29 \mathrm{a}$ & $0.18 \mathrm{a}$ & $0.27 \mathrm{a}$ & $1.79 \mathrm{~b}$ & $3.42 \mathrm{a}$ & $1.74 \mathrm{a}$ \\
\hline low degradable & $5.58 \pm$ & $3.10 \pm$ & $2.48 \pm$ & $140.05 \pm$ & $58.97 \pm$ & $38.63 \pm$ \\
sunflower seeds & $0.22 \mathrm{~b}$ & $0.21 \mathrm{a}$ & $0.23 \mathrm{~b}$ & $3.13 \mathrm{a}$ & $3.13 \mathrm{a}$ & $1.50 \mathrm{~b}$ \\
\hline
\end{tabular}

TP: total protein, Alb: albumin, G: glucose, Cho: cholesterol, TG: triglycerides, U: urea. a.b within the same column with different superscripts significantly at $(\mathrm{p} \leq 0.05)$ 
Most of the studies agreed that the seminal plasma is a complex mixture secreted from the testis, epididymis, and the auxiliary sexual glands, as it increases the ability and vitality of sperms for fertilization (Al-Madaly et al., 2016, Aslam et al., 2014). Sanchez-Luengo et al., (2004) reported that proteins have an important role in the development of sperm vitality and that the sperm plasma proteins maintain sperm motility, and protect sperm during the ejaculation process (Ashworth et al., 1994). The increase in the concentration of total protein and globulin in the seminal plasma in our study was associated with an increase in individual and mass motility and a reduction in the percentage of abnormal sperms (Yue et al., 2009, Gundogan et al., 2004). Umar et al., (2017) also indicated that there is a positive correlation between the percentage of individual motility and the concentration of sperm. Although the increase in urea concentration $46.20 \mathrm{mg} / \mathrm{dl}$ in the second treatment, but it was within the normal range (43-75) $\mathrm{mg} / \mathrm{dl}$, (Guo and others 2007), and this increase may be related to the increase of bypass protein intake from low sunflower meal. Moharrery et al., (2016) explained that the concentration of urea in the seminal plasma is more affected by the amount of nitrogen intake compared to its concentration in the blood plasma. On the other hand, the results were expected that feeding lambs on low degradable sunflower seeds increase the cholesterol and triglycerides in both blood and seminal plasma compared to the first and second treatments as a result of an increase in the amount of fat intake. This finding agreed with (Blom 1981, Cevik et al., 2008) they establish a positive correlation between blood and seminal plasma cholesterol, sperm concentration, and live sperm rate.

\section{CONCLUSION}

In conclusion, reducing the degradability of protein sources in the diet or feeding with oilseeds as a source of unsaturated fatty acids to the young lambs leads to an improvement in the semen characteristics and productivity of lambs.

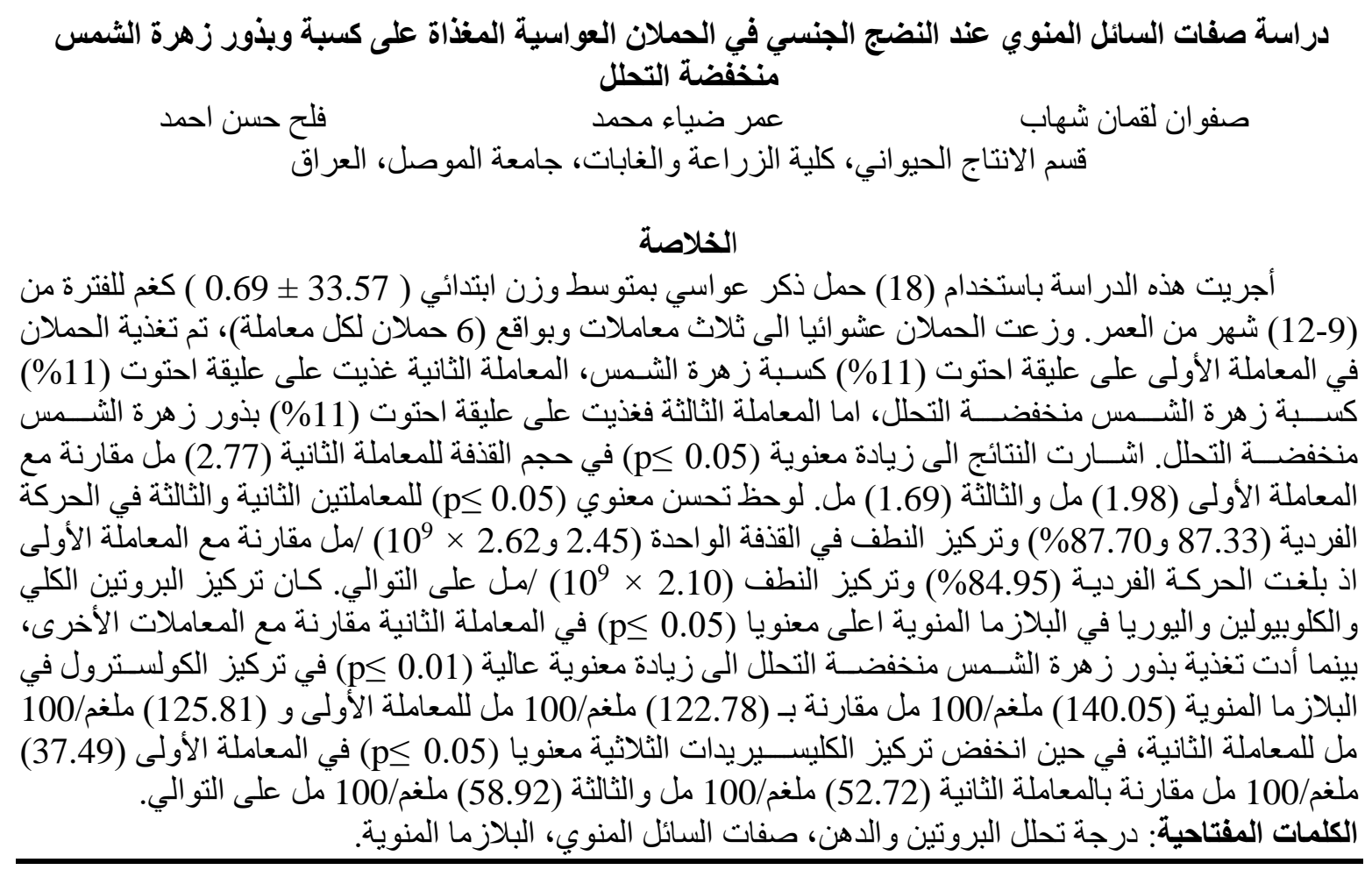




\section{REFERENCES}

Abdel-Ghani, A. A., Solouma, G. A., Kassab, A. Y., \& Soliman, E. B. (2011). Productive performance and blood metabolites as affected by protected protein in sheep. Open Journal of Animal Sciences, 1(2), 24-32.

Ajam, I. K., S. H., Abdul Karim \& H. M., Kamal. (1981). Physiology of Reproduction, Artificial Insemination, and Reproductive Care. faculty of Agriculture. Dar Al-Kutub for printing publishing. University of Al Mosul.1536.

Al-Hassan, F. H. A., (2009). Study of some reproductive traits and estimation of genetic parameters of body weight and testicular dimensions for rams and sexual maturity in Awassi and Hamdanid sheep. PhD thesis, Faculty of Agriculture and Forestry, University of Mosul.1-170.

Al-Hassan, F. H. A., (2018). Estimation of some hereditary and genetic parameters in the body weight and scrotum size of the uneasy lambs. Mesopotamia Journal of Agriculture.1, (46) :107-114.

Ali, M. F., El-Saidy, B., Mohsen, M. K., \& Khalafalla, M. M. E. (2005). Performance of lambs fed on ration containing soybean meal treated with formaldehyde and probiotics. ii. Productive and reproductive performance. Journal Nutrition Feed, 8(1), 511-527.

Al-Khawaja, A. K., E. Abdullah \& S. Abdul Ahad (1978). The chemical composition and nutritional value of Iraqi feed materials. A bulletin issued by the Nutrition Department of the General Livestock Directorate. Ministry of Agriculture and Agrarian Reform. The Republic of Iraq.34-40.

Almadaly, E. A., Farrag, Saadeldin, I. M., El-Magd, M. A., \& Abd El-Razek, I. M. (2016). Relationship between total protein concentration of seminal plasma and sperm characteristics of highly fertile, fertile and subfertile Barki ram semen collected by electroejaculation. Small Ruminant Research, 144, 90-99.

Al-Mallah, O. D. M., (2007). The effect of protein ratios in formaldehyde-treated diets on digestibility and production performance in goat lambs. PhD thesis, Faculty of Agriculture and Forestry, University of Mosul.1-220.

Anonymous , AOAC. (2000) Official Methods of Analysis, Association of Official Analytical Chemists, Arlington, Va, USA, 17th edition.

Anonymous, (2005). Statistical Analysis System. User's Guide for Personal Computer Release 8.2, SAS Institute, Inc., Cary, Nc, USA.

Ashworth, P. J., Harrison, R. A., Miller, N. G., Plummer, J. M., \& Watson, P. F. (1994). Survival of ram spermatozoa at high dilution: protective effect of simple constituents of culture media as compared with seminal plasma. Reproduction, Fertility and development, 6(2), 173-180.

Aslam, M. M., Kumaresan, A., Sharma, V. K., Tajmul, M., Chhillar, S., Chakravarty, A. K., ... \& Yadav, S. (2014). Identification of putative fertility markers in seminal plasma of crossbred bulls through differential proteomics. Theriogenology, 82(9), 1254-1262.

Blom, E. (1981). Studies on seminal vesiculitis in the bull: II. Proposal for a new classification of the spermiogram. Med Weter, 37, 239-242.

Cevik, M., Tuncer, P. B., TAȘDEMIR, U., \& Özgürtaş, T. (2008). Comparison of spermatological characteristics and biochemical seminal plasma parameters of 
normozoospermic and oligoasthenozoospermic bulls of two breeds. Turkish Journal of Veterinary and Animal Sciences, 31(6), 381-387.

Conquer, J. A., Martin, J. B., Tummon, I., Watson, L., \& Tekpetey, F. (2000). Effect of DHA supplementation on DHA status and sperm motility in asthenozoospermic males. Lipids, 35(2), 149-154.

Coulter, G. H., Cook, R. B., \& Kastelic, J. P. (1997). Effects of dietary energy on scrotal surface temperature, seminal quality, and sperm production in young beef bulls. Journal of Animal Science, 75(4), 1048-1052.

Duncan, D. B.1(955). Multiple range tests and F tests. Biometrics, 11, 1-42.

El-Zelaky, O.A, Khalifa E. I., Mohamed A. H., Mohamed B. K., \& Hussein A. M. (2011). Productive and reproductive performance of Rahmani male lambs fed rations containing Jatropha cake. Egyptian Journal of Sheep and Goats Sciences, 2:(6), 1-10.

El-Madawy, A, El-Sharawy M., Ali M., Hafez Y., Yamauchi N., \& Metwally E. S. (2019). Effect of Unsaturated Fatty Acids Supplementation on Productive and Reproductive Performance of Ram Lambs. Kyushu University Institutional Repository, 2, (64):247-255.

Ezazi, H., Abdi-Benemar, H., Taghizadeh, A., Khalili, B., Seifdavati, J., Jafaroghli, M., ... \& Salem, A. Z. (2019). The influence of dietary sunflower oil, rich in n-6 polyunsaturated fatty acids, in combination with vitamin $C$ on ram semen parameters, sperm lipids and fertility. Journal of the Science of Food and Agriculture, 8, (99): 3803-3810.

Fernández, M., Giráldez, F. J., Frutos, P., Hervás, G., \& Mantecón, A. R. (2005). Effect of undegradable protein concentration in the post-weaning diet on body growth and reproductive development of Assaf rams. Theriogenology, 8(63):2206-2218.

Fernandez, M., Giráldez, F. J., Frutos, P., Lavín, P., \& Mantecon, A. R. (2004). Ef,fect of undegradable protein supply on testicular size, spermiogram parameters and sexual behavior of mature Assaf rams. Theriogenology, 62(12): 299-310.

Fourie, P. J., Schwalbach, L. M., Neser, F. W. C., \& Van der Westhuizen, C. (2004). Scrotal, testicular and semen characteristics of young Dorper rams managed under intensive and extensive conditions. Small Ruminant Research, 12,(54):53-59.

Gimenez, D., \& Rodning S., (2007). Reproductive requirement of sheep and goat. Albama Cooperative Extention System. ANR-1316. Auburn University.

Gonzalez, R. A., Lucci, C. D. S., Cortada, C. N. M., Mazza Rodrigues, P. H., \& Rodrigues, R. R. (2000). Effects of dietary nitrogen level on semen characteristics of sheep. Brazilian Journal of Veterinary Research and Animal Science, 37(5), 00-00.

Gündoğan, M., Yeni, D., Uçar, M., \& Özenç, E. (2004). Relationship between some reproductive parameters and biochemical properties of blood serum in rams. Archives of andrology, 50(6), 387-390.

Guo, L., Zhao D., Song Y., Meng Y., Zhao H., Zhao X., \& Yang B., (2007). Reduced urea flux across the blood-testis barrier and early maturation in the male 
reproductive system in UT-B-null mice. American Journal of Physiology-Cell Physiology, 293(1), C305-C312.

Hadipour, A., Mohit A., \& Jahanian R., (2014). Effect of dietary supplementation of camel hump fat on performance, carcass characteristics, antibody responses and blood metabolites in fattening lambs. Small Ruminant Research, 119(13), 1-7.

Haro, A. N., Carro M. D., De Evan T., \& González J., (2020). Influence of feeding sunflower seed and meal protected against ruminal fermentation on ruminal fermentation, bacterial composition and in situ degradability in sheep. Archives of animal nutrition, 74(5), 380-396.

Hötzel, M. J., Markey C. M., Walkden-Brown S. W., Blackberry M. A., \& Martin G. B., (1998). Morphometric and endocrine analyses of the effects of nutrition on the testis of mature Merino rams. Reproduction, 113(2), 217-230.

Hussein, A., El-Badawy, M., \& Ashmawy, T. (2018). Effect of tannin protected sunflower meal without or with chamomile flowers supplementation on productive performance of zaraibi dairy goats and their offspring. Journal of Animal and Poultry Production, 9(2), 57-66.

Kumar, A., Singh, P., Bhakat, M., Singh, S., Nitharwal, K., \& Gupta, A. K. (2017). Effect of feed energy levels on semen quality and freezability of young murrah buffalo bulls. Buffalo Bulletin, 36(2), 415-426.

Labuschagné, H. S., Schwalbach, L. M. J., Taylor, G. J., \& Webb, E. C. (2002, May). The effect of age on reproductive and productive characteristics of young Bonsmara bulls fed a high-energy diet. In 39th National Congress of the South African Society of Animal Science, Christiana, South Africa.

Loskutoff, N. M., \& Crichton E. G., (2001). Standard operating procedures for genome resource banking. The Bill and Bernience Grewcock Center for Conservation and Research, Omaha's Henry Doorly Zoo, 1-16.

Majewska, M. Pająk P., Skomiał J. J., \& Kowalik, J. B., (2016). The effect of different forms of sunflower products in diets for lambs and storage time on meat quality. Animal feed science and technology, 222, 227-235.

Martin, G. B., Walkden-Brown, S. W., Boukhliq, R. A. C. H. I. D., Tjondronegoro, S. O. E. D. J. I. H. A. R. T. I., Miller, D. W., Fisher, J. S., \& Adams, N. R. (1994). Non-photoperiodic inputs into seasonal breeding in male ruminants. Perspectives in comparative endocrinology, 574-585.

Moharrery, A., Rezaei R., \& Zamiri M. J., (2016). Is there a relationship between nitrogen intake and testicular urea concentration. CIBTech. Journal. Zoology. Vol 5(3):32-39.

Oldham, C. M., Adams, N. R., Gherardi, P. B., Lindsay, D. R., \& Mackintosh, J. B. (1978). The influence of level of feed intake on sperm-producing capacity of testicular tissue in the ram. Australian Journal of Agricultural Research, 29(1), 173-179.

Pinilla, L., Aguilar, E., Dieguez, C., Millar, R. P., \& Tena-Sempere, M. (2012). Kisspeptins and reproduction: physiological roles and regulatory mechanisms. Physiological reviews, 92(3), 1235-1316.

Radmanesh, A., Darmani Kuhi, H., \& Riaci, A. (2015). Relationship of dietary fat sources with semen characteristics, blood plasma metabolites and scrotal 
circumference in mature rams. Iranian Journal of Applied Animal Science, 5(3), 623-628.

Safarinejad, M. R., Hosseini, S. Y., Dadkhah, F., \& Asgari, M. A. (2010). Relationship of omega-3 and omega- 6 fatty acids with semen characteristics, and anti-oxidant status of seminal plasma: a comparison between fertile and infertile men. Clinical nutrition, 29(1), 100-105.

Saleh, M. N. A., (2009). The use of reduced feed hydrolysis in improved Awassi sheep feeding and its effect on production and reproductive performance. $P h D$ thesis, Faculty of Agriculture and Forestry, University of Mosul.1-195.

Sánchez-Luengo, S., Aumüller, G., Albrecht, M., Sen, P. C., Röhm, K., \& Wilhelm, B. (2004). Interaction of PDC-109, the major secretory protein from bull seminal vesicles, with bovine sperm membrane Ca2+-ATPase. Journal of andrology, 25(2), 234-244.

Shamoun, S. A., Al-Mallah O.D., Tayyib M. A., (2011). The effect of adding sunflower seeds to dietary components on some semen characteristics and some blood measurements in Awassi rams. Al-Rafidain Agriculture Journal. Volume (39) Issue (1).

Smith, J.T. \& Mayer D., (1955). Evaluation of sperm concentration by the haemocytometer method. Comparison of four counting fluids. Fertility and Sterility, 6: 271-275.

Umar, S., Ahmad, M., Ahmad, I., Zubair, M., Umar, Z., Qureshi, A. S., \& Shaukat, A. (2018). Correlation of biochemical constituents of seminal plasma with semen quality in Teddy goat (Capra hircus) bucks. Andrologia, 50(3), e12940.

Yasothai, R. (2014). Importance of protein on reproduction in dairy cattle. Int. J. Sci. Environ. Technol, 3, 2081-2083.

Yue, W., Shi, L., Bai, Z., Ren, Y., \& Zhao, Y. (2009). Sodium dodecyl sulfate (SDS)polyacrylamide gel electrophoresis of ram seminal plasma proteins and their correlation with semen characteristics. Animal Reproduction Science, 116(34), 386-391.

Zaghloul, H. K. (2015). Effect of different dietary protein sources on morphohistometry of testes and epididymis, libido and epididymal, sperm function in sheep. Egyptian Journal. of Nutrition and Feeds, 18(3):347-358. 